\title{
ALDH2 wt Allele
}

National Cancer Institute

\section{Source}

National Cancer Institute. ALDH2 wt Allele. NCI Thesaurus. Code C84925.

Human ALDH2 wt allele is located in the vicinity of $12 \mathrm{q} 24.2$ and is approximately $43 \mathrm{~kb}$ in length. This allele, which encodes aldehyde dehydrogenase mitochondrial protein, plays a role in intermediary metabolism. Mutations in this gene are associated with increased risk of esophageal carcinoma. 